\title{
Treatment and Effective Utilization of Greywater: A Preliminary Case Study
}

\author{
Sneha Gautam *, Lakshmi M. Makhitha, Anirudh Gupta, J. Brema, E. J. James and Gajendran Chellaiah \\ Department of Civil Engineering, Karunya Institute of Technology and Sciences, Coimbatore 641114, India; \\ makitha@karunya.edu.in (L.M.M.); anirudhgupta@karunya.edu (A.G.); brema@karunya.edu (J.B.); \\ ejjames@karunya.edu (E.J.J.); gajendran@karunya.edu (G.C.) \\ * Correspondence: snehagautam@karunya.edu or gautamsneha@gmail.com
}

check for updates

Citation: Gautam, S.; Makhitha, L.M.; Gupta, A.; Brema, J.; James, E.J.; Chellaiah, G. Treatment and Effective Utilization of Greywater: A Preliminary Case Study. Appl. Syst. Innov. 2021, 4, 16. https://doi.org/ $10.3390 /$ asi4010016

Received: 29 January 2021

Accepted: 18 February 2021

Published: 25 February 2021

Publisher's Note: MDPI stays neutral with regard to jurisdictional claims in published maps and institutional affiliations.

Copyright: (c) 2021 by the authors. Licensee MDPI, Basel, Switzerland. This article is an open access article distributed under the terms and conditions of the Creative Commons Attribution (CC BY) license (https:// creativecommons.org/licenses/by/ $4.0 /)$.

\begin{abstract}
Greywater has been identified as a valuable alternative water source over recent years. Few practices (i.e., recycling and reuse) of greywater have attracted global attention in meeting the future water demand. However, essential parameters should be analyzed for reliable reuse and treatment. The present study addresses the possibilities of the alternative source with the treated greywater. Gravity-governed flow methods through a column containing gravel, sand, and activated carbon was applied. The quality of treated greywater from the university campus, which included physical, chemical, and biological parameters, was assessed to check non-potable reuse suitability. The reduction percentage of organics in biological oxygen demand and chemical oxygen demand was $64 \%$ and $42 \%$, respectively. Similarly, the reduction percentage was obtained at $74 \%$ and $66 \%$ for turbidity and electrical conductivity. The removal efficiency was $57 \%, 77 \%, 48 \%$, and $44 \%$ for total dissolved solids, alkalinity, chlorides, and total hardness. The $\mathrm{pH}$ of treated water samples was found in the neutral range suggesting its suitability for reuse. Hence, the proposed greywater treatment method is a cost-effective and straightforward approach to reuse greywater for irrigation, watering the lawns, and car washing. The greywater collected can be disinfected immediately and reused with minimal possibility of regrowth of microorganisms.
\end{abstract}

Keywords: biological parameters; greywater; filtration; physical and chemical parameters; wastewater reuse

\section{Introduction}

The United Nations highlighted the SDGs (sustainable development goals) for 2030, where the sixth objective is to represent clean water and wastewater treatment [1]. In developing countries, thousands of deaths were reported due to waterborne diseases, and these results indicate the massive failure to reach the sixth objective of SDGs. With various types of technologies, several decentralized wastewater treatment plants have been installed in developing countries [2].

Few researchers [3,4] have referred to developing nations' current opinions about decentralized wastewater treatment systems for big/megacities' sanitation systems as effective and robust. On the other hand, Roefs et al. [5] conducted a comparison study of three different wastewater treatment plants (i.e., hybrid, centralized, and decentralized) to understand the issues with the economic perspectives of urban growth. The outcome of the mentioned research is the possible advantages in terms of total discounted lifetime costs. In the second opinion, a decentralized treatment will be more advantageous for lower population growth than expected and lower idleness of the treatment plant. Moreover, centralized treatment plants need a more complicated treatment system to achieve the same quality of treated wastewater with a significant amount of carbon dioxide and energy consumption [6].

The decentralized solution is now highly adopted because of low environmental impact association rather than the construction of sewer networks to connect the users 
to centralized plants [7]. Nowadays, decentralized wastewater management is prevalent and demanding due to economic, social, and environmental advantages [7]. According to WWAP [8], decentralized treatment systems could be another suitable way to the academic/university campus, rural area, or even in some peri-urban regions, where it's challenging to install traditional treatment plants. Simultaneously, greywater could be treated near the sources where it is coming from, and the treated water could be reused/distributed close to or at the same site of the treating unit.

The small household technique to treat wastewater can be used as decentralized treatment systems. The treatment unit's important highlight is low capital and less operational expenditure occupying small areas other than traditional wastewater treatment unit/plants. The present form of treatment plant has few qualities (i.e., simple operations and annexation of natural gravity-based technologies to reuse the wastewater in situ) to show the low-cost method's main advantages with unique household techniques over traditional plants [9]. In higher pollution, water scarcity, and unsustainable development practices, the demand for treated water will increase in cities/society and academic campuses [1]. Many water demands (i.e., gardening, car washing, floor cleaning, etc.) by institutions and university campuses can be achieved by low-cost treatment units [10-12].

Therefore, to reduce the water demand for future sustainability, a simple operation and low-cost method with a unique household technique was introduced to reuse the greywater from the university campus's administrative block. The present work aims to reduce the demand for water or groundwater extraction subsequently. A small unit for greywater treatment is installed in Karunya Institute of Technology and Sciences, an academic campus to manage the administrative block's greywater. The main objective is to develop a low-cost and effective method to treat greywater using gravity-governed filtration techniques.

\section{Materials and Methodology}

A gravity-governed method has been applied, where natural strata were used to treat the greywater. Also, applied bleaching powder to the disinfection process. Filtration media was prepared by using a column packed with filtration media (i.e., cotton, activated carbon, sand (fine $(<0.5 \mathrm{~mm})$ and coarse $(1.0 \mathrm{~mm} / 0.5 \mathrm{~mm}))$, and gravel (small- $(4.0 \mathrm{~mm} / 2.0 \mathrm{~mm})$ and big $(4.0 \mathrm{~mm} / 12.0 \mathrm{~mm}))$. Where activated carbon $(<1.0 \mathrm{~mm})$ captures color, odor, and organic pollutants, sand, and gravel capture suspended solids and microorganisms. The volume of the material used in cubic $\mathrm{cm}$ (i.e., activated carbon-82, fine sand-191, coarse sand-191, small gravel-318, big gravel-382). The selection of filtration media was based on previously published articles [13-15].

A schematic diagram of the proposed greywater treatment is shown in Figure 1.

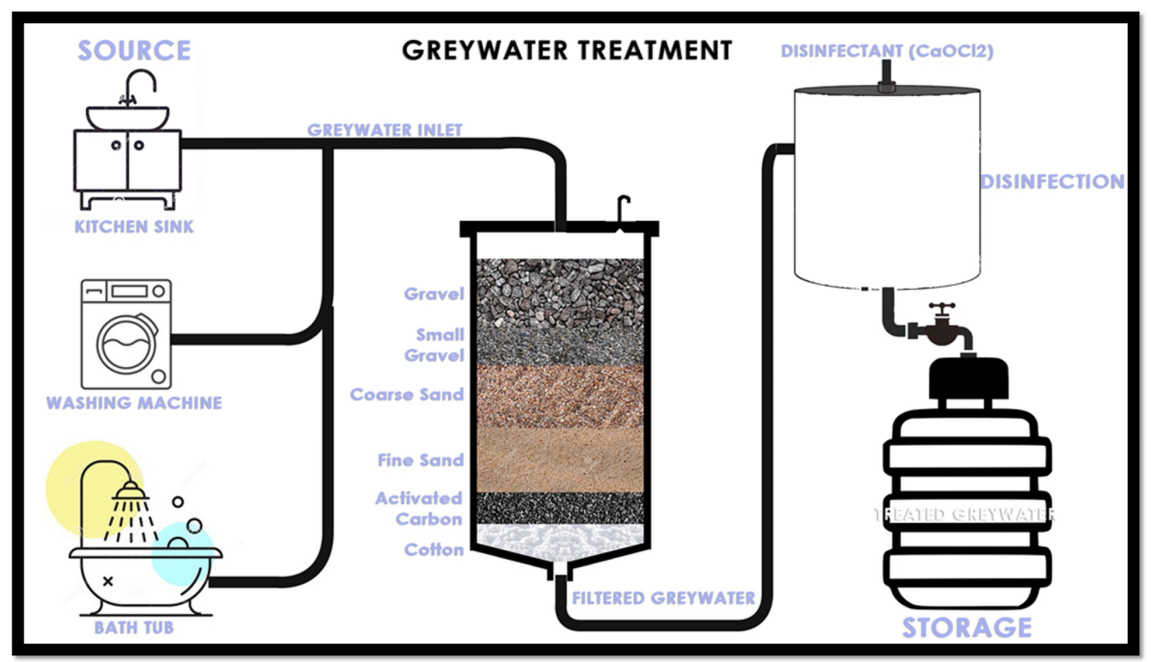

Figure 1. A schematic diagram of the proposed greywater treatment procedure. 
A total of 30 samples were collected from the five outlets of the administrative block of Karunya institute of technology and sciences; the three liters of greywater collected from different outlets was passed through the compact column (height $=25 \mathrm{~cm}$; radius $=4.5 \mathrm{~cm}$ ) containing the other layers (i.e., gravel (big and small), sand (coarse and fine), activated carbon, and cotton). The flow was $6.5-7.5 \mathrm{~mL} / \mathrm{min}$, where a total of 5-6 L of greywater were allowed to pass through the proposed packed column was collected as treated water. In changing the filtration media, fresh materials have been used again when it was completely clogged. Bleaching powder $\left(\mathrm{CaOCl}_{2}-0.05 \mathrm{~g} / \mathrm{L}\right)$ was applied to the disinfection process. The physio-chemical and microbiological analyses were carried out in Pure and Pure Aqua Laboratory, Trichy, Tamilnadu, India to examine greywater and treated water. We analyzed according to standard $\mathrm{pH}$, electrical conductivity, Biological Oxygen Demand (BOD), Chemical Oxygen Demand (COD), turbidity, alkalinity, chlorides, total dissolved solids (TDS), Escherichia coli, and residual chlorine, biofilm formation).

\section{Results and Discussion}

The various parameters of physical, chemical, and biological (i.e., $\mathrm{pH}$, electrical conductivity, TDS, alkalinity, chlorides, total hardness, turbidity, BOD, COD, HLR, OLR, residual chlorine, E. coli, and biofilm formation) of the untreated and treated wastewaters were estimated.

\subsection{Physical Parameters \\ 3.1.1. Turbidity}

The percentage reduction in turbidity of various water samples (Figure 2) was found to be in the range of $50-74 \%$. The maximum and minimum percentage reduction in turbidity was found in the cases of sample No. 24 and No. 21, respectively. The mean reduction in turbidity of the various water samples was found to be $58 \%$. Turbidity is an indirect measure of suspended solids, and it is vital for maintaining the effectiveness of disinfection technology [16]. Monitoring turbidity is crucial in controlling the aesthetic condition of the treated greywater [17]. The high percentage reduction in the turbidity and the presence of turbidity of the treated samples within the permissible limits indicated that the greywater might be suitable for reuse after treatment.

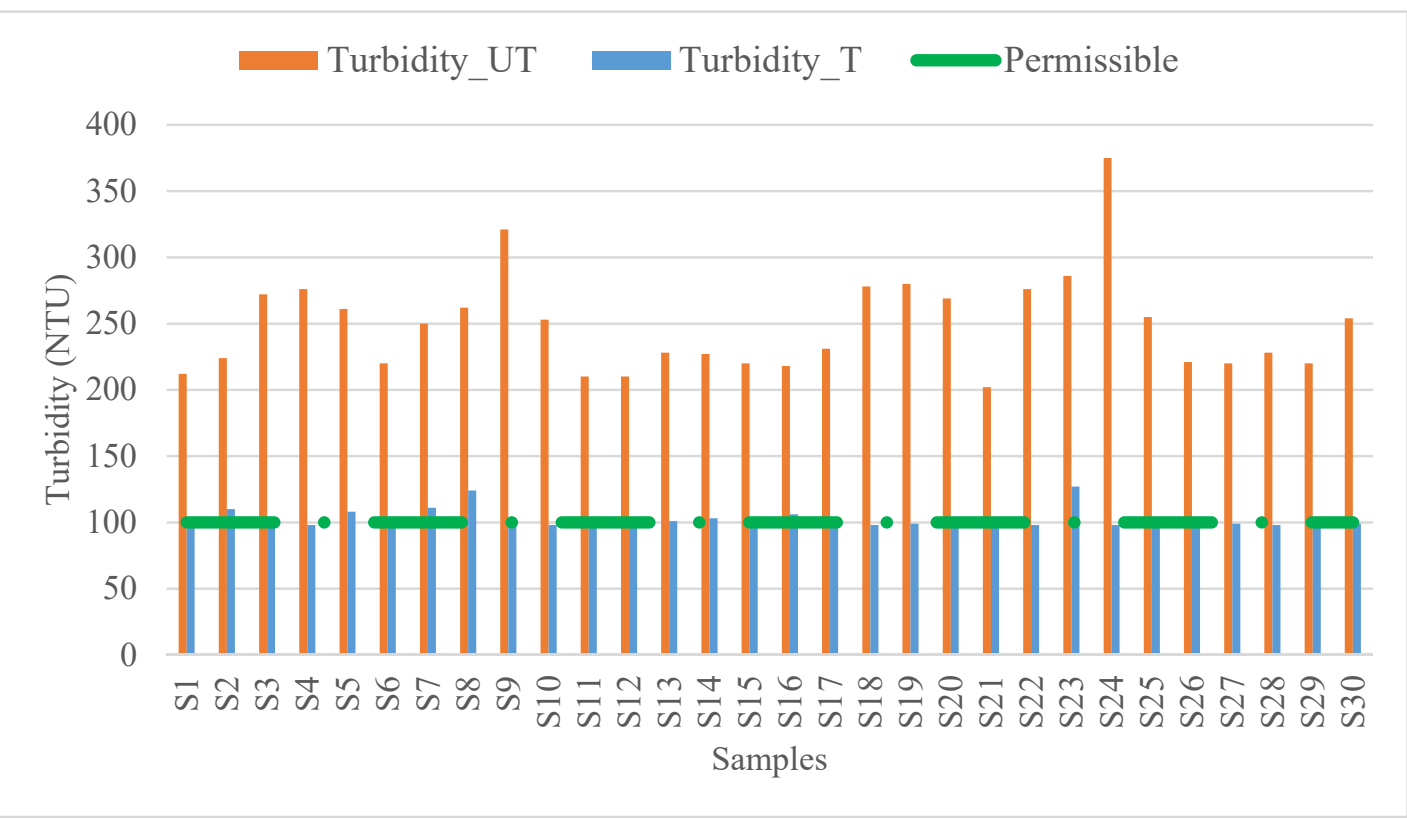

Figure 2. Turbidity of untreated (UT) and treated (T) samples and permissible limits. 


\subsubsection{Electrical Conductivity}

There was a 44-66\% reduction in the various water samples (Figure 3). Sample No. 23 showed the minimum decrease in electrical conductivity, whereas sample No. 28 delivered the same maximum reduction parameter. The average reduction in electrical conductivity of the various water samples was observed as $53 \%$.

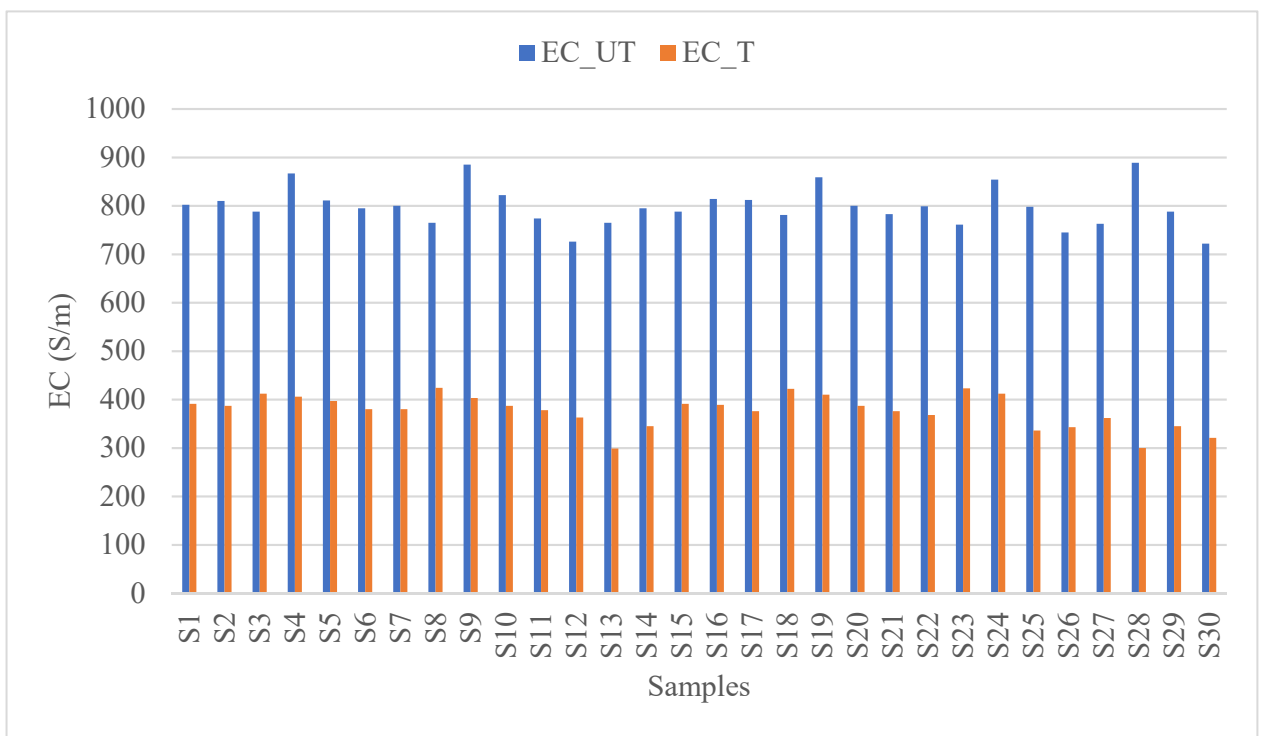

Figure 3. Electrical conductivity of untreated (UT) and treated (T) samples.

\subsection{Chemical Parameters}

\subsection{1. $\mathrm{PH}$}

By USEPA guidelines, the treated water samples' $\mathrm{pH}$ must be in the range of $\sim 6-9$ for suitable reuse $[16,17]$. Figure 4 shows that the $\mathrm{pH}$ of the treated water samples was around the neutral range (i.e., 6-7), suggesting that it can be used for reuse after treatment.

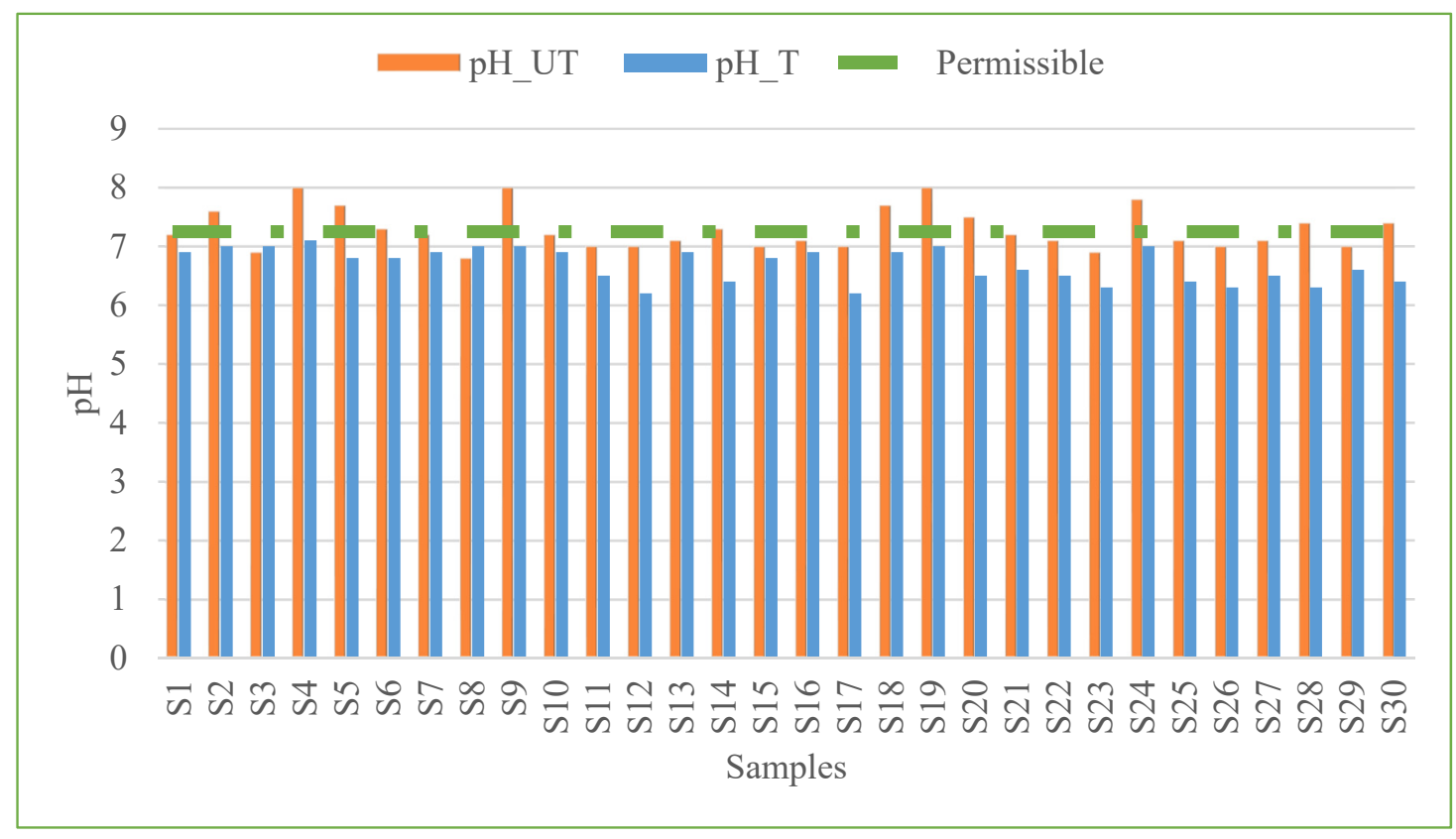

Figure 4. $\mathrm{pH}$ of untreated (UT) and treated $(\mathrm{T})$ water samples and permissible limits. 


\subsubsection{TDS}

We found the percentage of reduction in TDS of the various water samples (Figure 5) to be in the range of $48-57 \%$. In sample No. 2, the maximum percentage of TDS reduction was obtained, whereas the minimum percentage of decrease in TDS was obtained in the case of sample No. 25. The mean percentage of reduction in TDS was obtained as $54 \%$. The high percentage of reduction in TDS and its presence within the permissible limits suggests that the greywater is suitable for reuse after treatment.

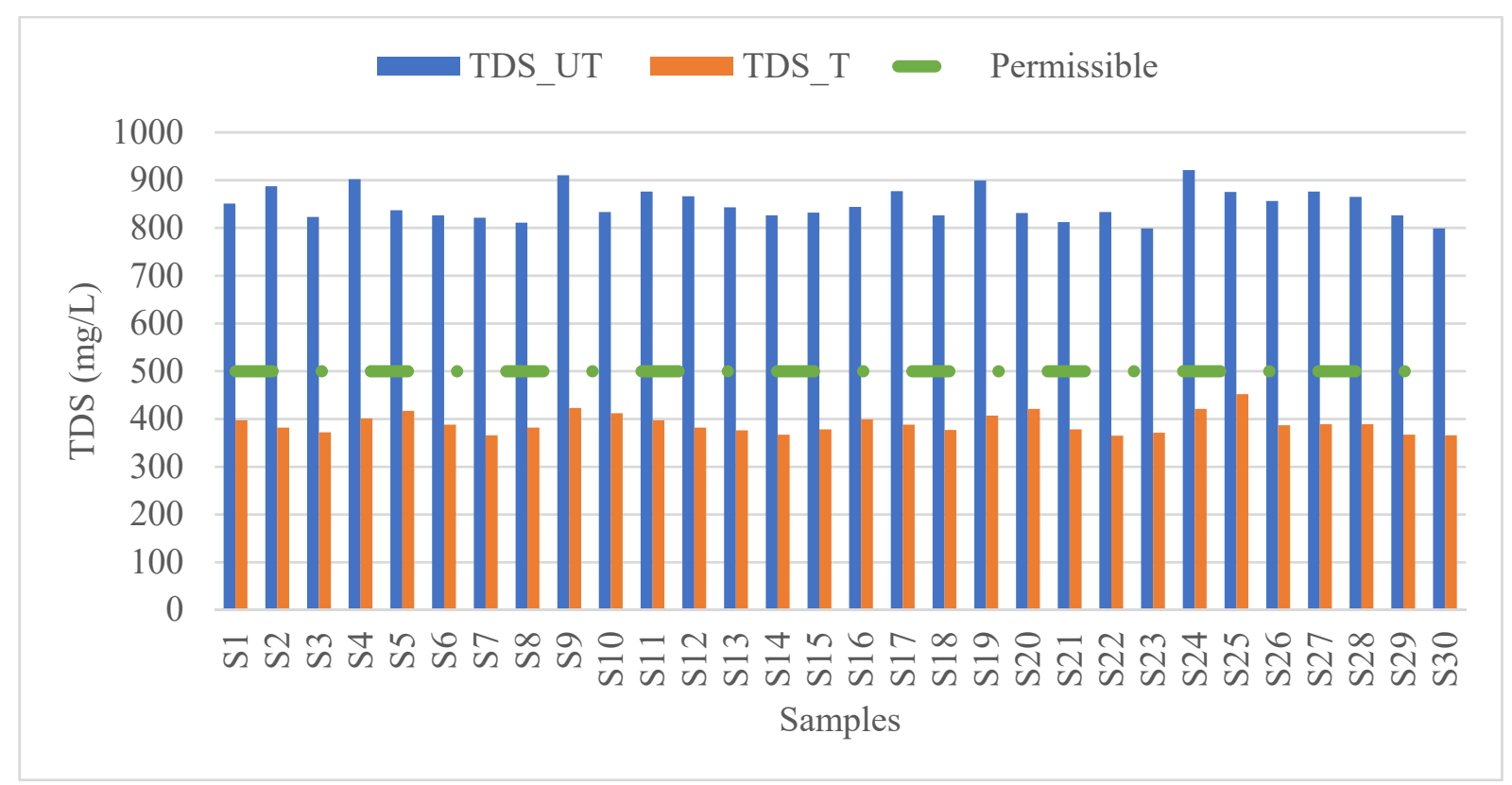

Figure 5. TDS of untreated (UT) and treated (T) water samples and permissible limits.

\subsubsection{Alkalinity}

The percentage of reduction in alkalinity of the various water samples (Figure 6a) was found to be in the range of $29-77 \%$. The maximum and minimum percentage of alkalinity reduction was obtained in sample No. 10 and No. 12, respectively. The mean value of percentage reduction in alkalinity of the various water samples was $46 \%$. The treated samples' alkalinity was within the permissible limits and indicated that they might suitably reuse the greywater.

\subsubsection{Chlorides}

There was a $27-48 \%$ reduction in the various water samples (Figure $6 \mathrm{~b}$ ). The maximum and minimum reduction in chlorides was found in sample No. 1 and No. 23, respectively. The mean value of percent reduction in chlorides of the various water samples obtained was $35 \%$. The reuse of greywater is indicated by the fact that the treated samples' chloride content was within the permissible limits.

\subsubsection{Total Hardness}

The percentage of reduction in total hardness of the various water samples (Figure 7) was observed in the range of $8-44 \%$. Sample No. 1 and No. 22 showed the maximum reduction in total hardness, whereas sample No. 4 showed the minimum decrease in total hardness. The mean value of percentage reduction in the various water samples' total hardness was observed as $23 \%$.

\subsubsection{BOD}

The percentage of BOD reduction of various water samples (Figure 8a) was observed in the range of $28-64 \%$. In samples No. 4 and No. 9, the maximum percentage of BOD 
reduction was obtained, whereas the minimum percentage of BOD reduction was obtained in the case of sample No. 20. The mean value of the percentage of decrease in BOD of the various water samples was $51 \%$. It suggested that the biodegradable organic compounds may be suitably removed through this treatment process [16]. Since the BOD of most of the treated samples was within the permissible limits, the greywater was found to be suitable for reuse.
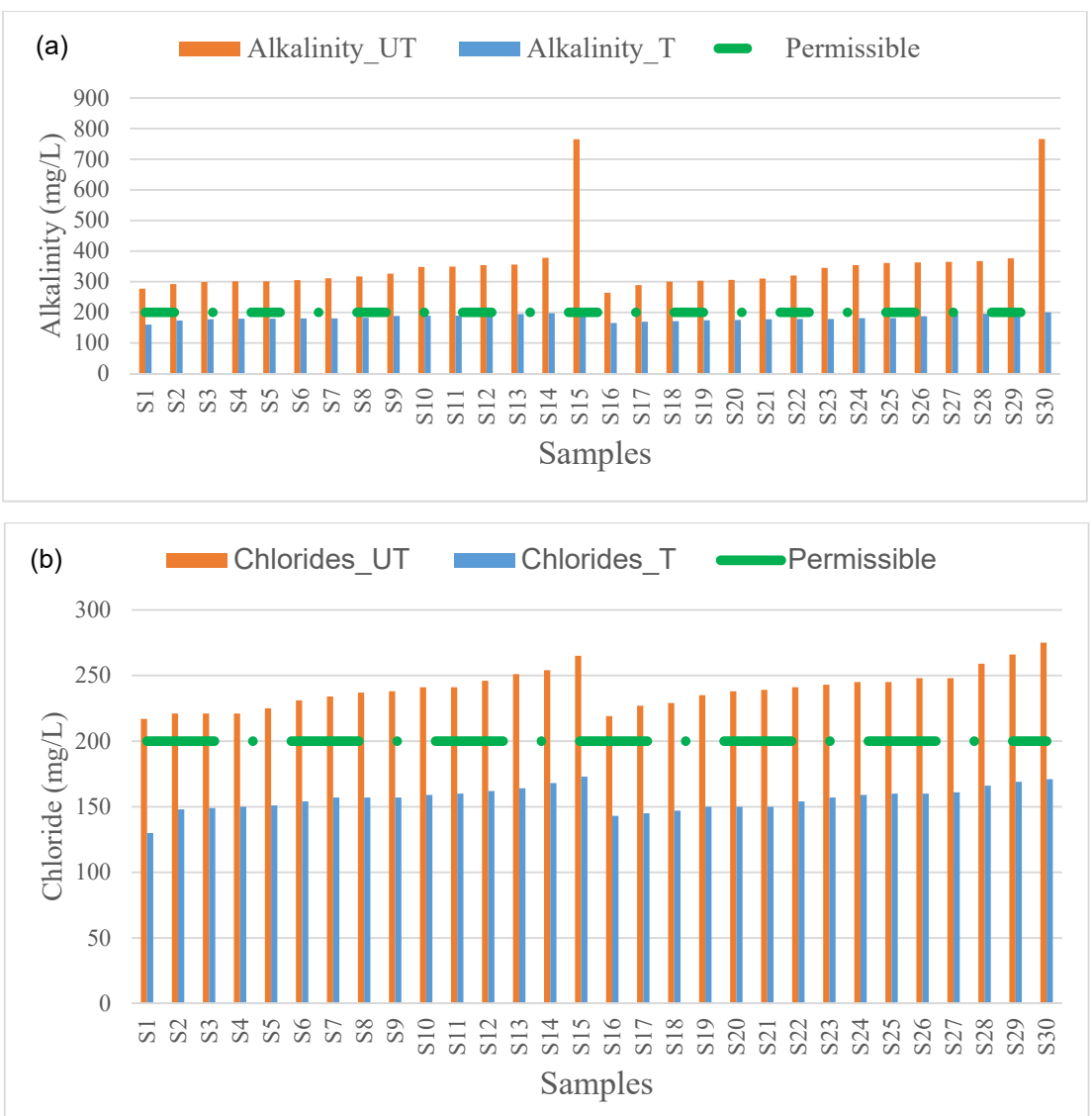

Figure 6. Alkalinity (a) and chlorides (b) of untreated (UT) and treated (T) samples and permissible limits.

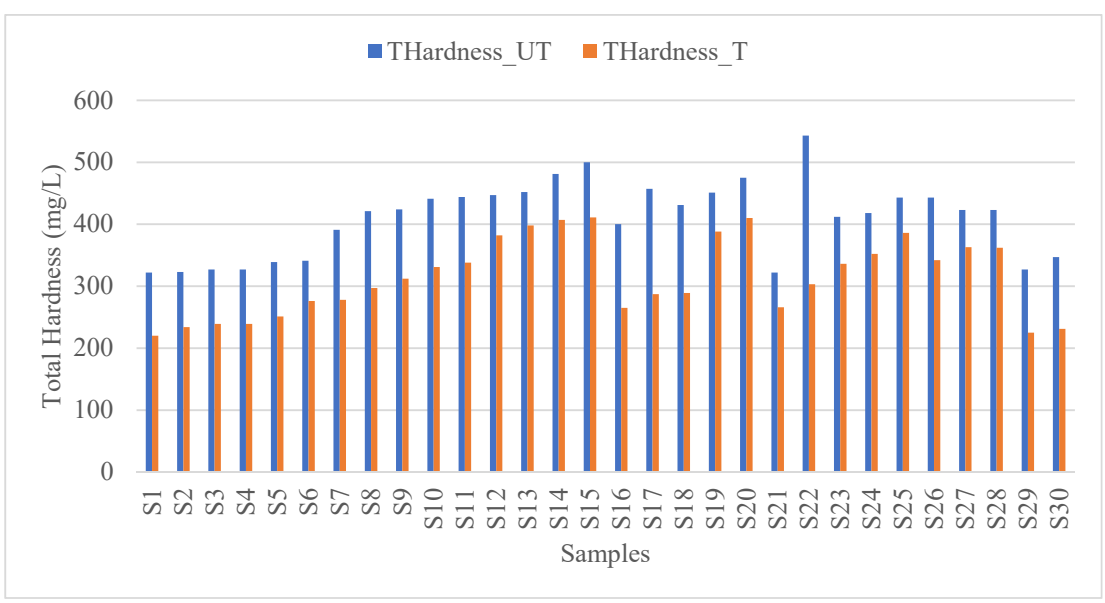

Figure 7. Total hardness in untreated (UT) and treated (T) samples. 


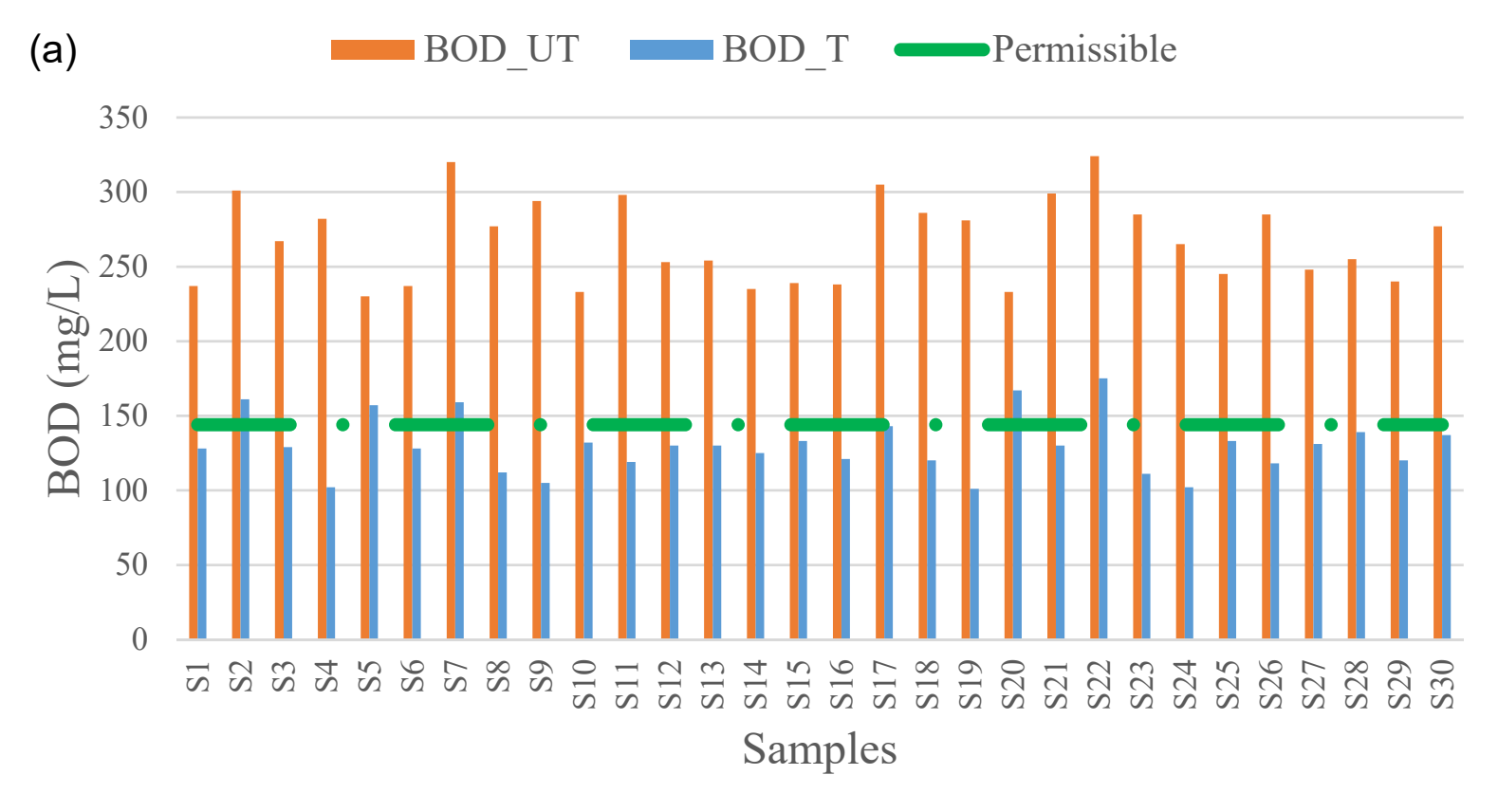

(b)
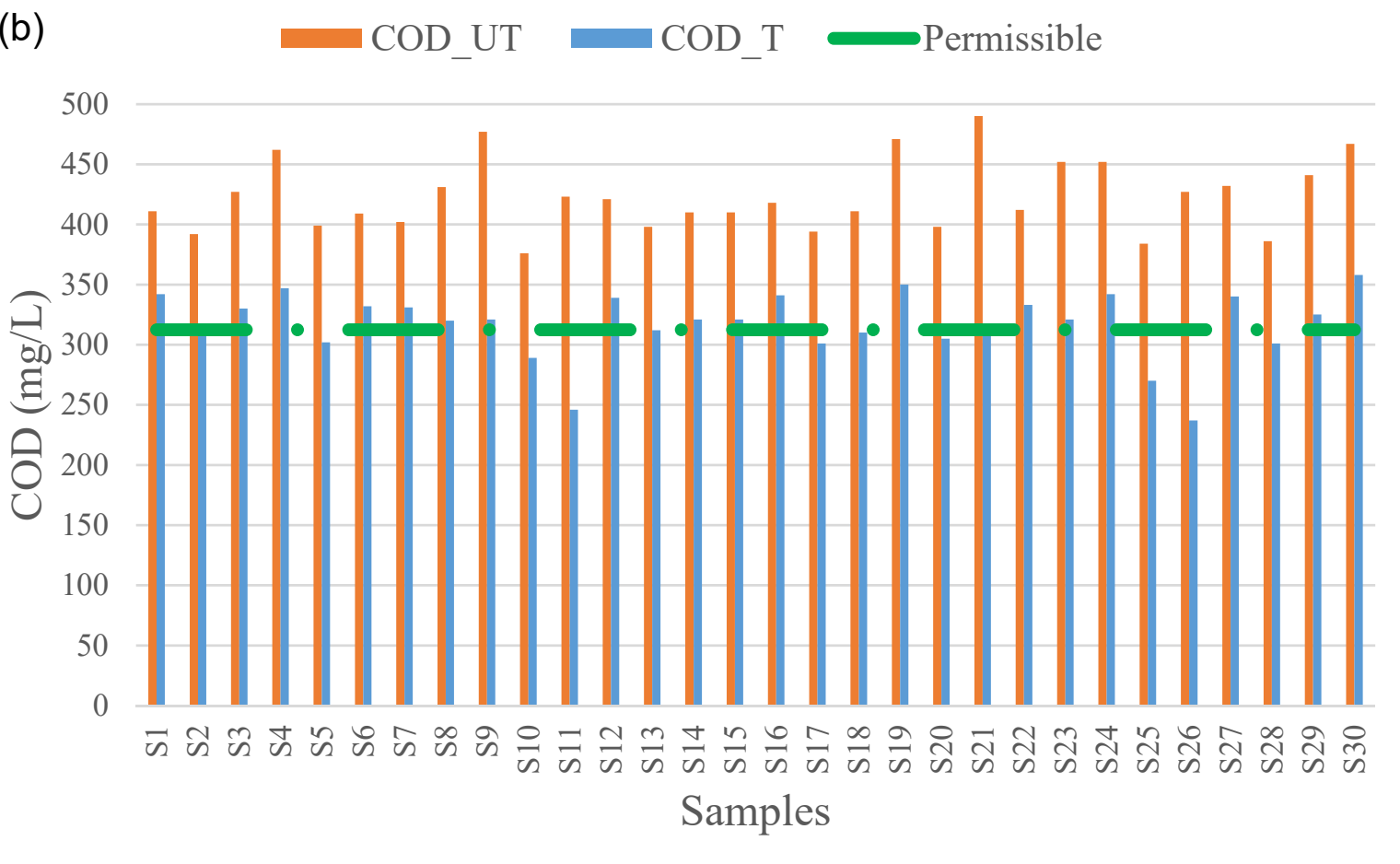

Figure 8. BOD (a) and COD (b) of untreated (UT) and treated (T) samples and permissible limits.

\subsubsection{COD}

There was a reduction of $17-42 \%$ in COD of the various water samples (Figure $8 b$ ). The maximum and minimum percentage of reduction in the case of sample No. 26 and No. 1, respectively. The mean percentage of reduction in COD of various water samples was found to be $25 \%$. The lower COD removal maybe because the recalcitrant organic compounds may be present in higher proportions in the greywater and could not be efficiently removed during the treatment process [16]. However, the suitable reuse of greywater is possible since the COD of the treated water samples was within the permissible 
limits. The high percent reduction in turbidity and BOD values of the treated water samples indicate that the greywater is suitable for non-potable reuse after treatment.

\subsection{Biological Parameters}

\subsubsection{E. coli Check and Biofilm Formation}

The MPN (most probable number) of $E$. coli content in treated water was 5.7 per $100 \mathrm{~mL}$. It was within the maximum permissible limit of 23 per $100 \mathrm{~mL}$ [16,18]. It indicated the safety of viral infections. There was no biofilm formation in the media as per the governance of four months.

\subsubsection{Organic Loading Rate (OLR) and Hydraulic Loading Rate (HLR)}

OLR expresses the amount of organic matter fed into a system in BOD [19-22]. The OLR ranges from 0.001919 to 0.0027 with a mean and standard deviation of 0.0022 and 0.00023 , respectively. The hydraulic loading rate (HLR) of the wastewater treatment process unit was $0.041 \mathrm{~m}^{3}$ per $\mathrm{m}^{2}$ per day.

\subsubsection{Residual Chlorine Check}

A residual chlorine check is one of the most effective methods for checking microbial contaminations in wastewater streams [23-26]. Chlorine is one of the effective chemicals in destroying a variety of organisms such as bacteria, viruses, and protozoa, including Salmonella, Shigella, and Vibrio cholerae. This method of chlorination is widely practiced in wastewater treatment methods in order to reduce microbial contamination. This also decreases the risk of exposure to diseases due to microbial populations. By-products are formed due to the addition of chlorine or any chemical disinfectant to wastewater. The presence of ammonia and the prior condition of the sewage have a considerable impact on the by-product formation. Dechlorination of excess chlorine is highly essential prior to utilization in order to conserve aquatic life and also to reduce the impact of the intensity of disinfection by-products. The residual chlorine content in treated water after chlorination was $0.1-0.2 \mathrm{mg} / \mathrm{L}$. It was within the permissible limit of $1 \mathrm{mg} / \mathrm{L}[16,17]$ (Arden and Ma., 2018; Oh et al. 2017). It indicated that the water was free from excess residual chlorine content.

The E. coli check and residual chlorine check suggested that the greywater is suitable for non-potable reuse after treatment. However, quantitative microbial risk assessment can be included to check the microbial risk involved in the non-potable reuse of greywater [27]. Furthermore, economic analysis can be planned in the future [28]. For possible water reuse in the agricultural sector, the retention of nutrients (i.e., total nitrogen and orthophosphate) must also be investigated [29]. In addition, the overall treatment of greywater can also be improved suitably by using a combination of treatment processes (such as membranes and coagulation) to obtain high-quality treated water for irrigation purposes [30].

\section{Conclusions}

A comprehensive characterization of greywater is essential to the design of a zero liquid discharge treatment system. In this regard, greywater samples were collected from the university campus to assess the characterization of physical, chemical, and biological parameters and their removal efficiency after passing through the column containing gravel, sand, and activated carbon. The percentage of BOD reduction was as high as $64 \%$, showing suitable removal of the biodegradable organic compounds through this treatment process. Convenient reuse of greywater can be planned since the COD of the treated water samples was within the permissible limits, and $\mathrm{pH}$ was also in the neutral range. E. coli and residual chlorine checks also indicated the non-potable reuse of the treated greywater after treatment. The proposed methods' output motivates a different outlook towards the considerable scale benefits in reducing water scarcity and sustaining the water for future use. The developed design is simple, eco-friendly, economically viable, and installed in 
every academic campus. Similarly, treated greywater can be used for car washing, watering the lawns, and irrigation purposes on the campus.

With an increased shortage of water, where one-third of the world's population have no access to clean water, greywater reuse plays a vital role. Conversion of significant wastewater to reusable water using nature-based solutions (NBS) is quite challenging. Though greywater reuse has positive impacts such as facing a shortage of water resources, reducing sewage quantity, minimizing the water supply costs, and enhancing the availability of organic matter and nutrients, it also has negative impacts such as microbial risks and metals micro pollutants. Future research needs to be done to study the pros and cons of greywater treatment procedures.

Author Contributions: Conceptualization, S.G.; data curation, S.G. and L.M.M.; formal analysis, S.G. and A.G.; methodology, A.G.; resources, J.B.; software, J.B.; supervision, E.J.J.; visualization, G.C.; writing —original draft, S.G. and A.G.; writing-review \& editing, S.G. All authors have read and agreed to the published version of the manuscript.

Funding: This research was funded by Karunya Institute of Technology and Sciences Coimbatore under the Karunya Short Term Grant (Seed Money for Research).

Institutional Review Board Statement: Not applicable.

Informed Consent Statement: Not applicable.

Data Availability Statement: Data sharing not applicable.

Acknowledgments: S.G. is thankful to the Karunya Institute of Technology and Sciences, Coimbatore, Tamil Nadu, India, to provide us the required data sets and support during analysis.

Conflicts of Interest: The authors declare no conflict of interest.

\section{References}

1. UNDP. Goal 6: Clean Water and Sanitation. Available online: https://www.undp.org/content/undp/en/home/sustainabledevelopment-goals/goal-6-clean-water-and-sanitation.html (accessed on 6 June 2020).

2. Singh, N.K.; Kazmi, A.A.; Starkl, M. A review on full-scale decentralized wastewater treatment systems: Techno-economical ap-proach. Water Sci. Technol. 2015, 71, 468-478. [CrossRef] [PubMed]

3. Abou-Elela, S.I.; Hellal, M.S.; Aly, O.H.; Abo-Elenin, S.A. Decentralized wastewater treatment using passively aerated biological filter. Environ. Technol. 2017, 40, 250-260. [CrossRef] [PubMed]

4. International Water Association-IWA. Wastewater Report 2018. The Reuse Opportunity. Cities Seizing the Reuse Opportunity in a Circular Economy; IWA Publishing: London, UK, 2018.

5. Roefs, I.; Meulman, B.; Vreeburg, J.H.; Spiller, M. Centralised, decentralised or hybrid sanitation systems? Economic evaluation under urban development uncertainty and phased expansion. Water Res. 2017, 109, 274-286. [CrossRef] [PubMed]

6. Matos, C.; Pereira, S.; Amorim, E.V.; Bentes, I.; Briga-Sá, A. Wastewater and greywater reuse on irrigation in centralized and de-centralized systems-an integrated approach on water quality, energy consumption and $\mathrm{CO}_{2}$ emissions. Sci. Total Environ. 2014, 493, 463-471. [CrossRef]

7. Fane, A.; Fane, S. The role of membrane technology in sustainable decentralized wastewater systems. Water Sci. Technol. 2005, 51, 317-325. [CrossRef]

8. WWAP (UNESCO World Water Assessment Programme). The United Nations World Water Development Report 2019: Leaving No One Behind; UNESCO: Paris, France, 2019.

9. Chernicharo, C.A.L. Princípios do Tratamentobiológico de Aguasresiduárias: Reatoresanaeróbios, 2nd ed.; UFMG: Belo Horizonte, Brasil, 2016.

10. Petousi, I.; Daskalakis, G.; Fountoulakis, M.; Lydakis, D.; Fletcher, L.; Stentiford, E.; Manios, T. Effects of treated wastewater irrigation on the establishment of young grapevines. Sci. Total. Environ. 2019, 658, 485-492. [CrossRef]

11. Jabri, K.M.; Nolde, E.; Ciroth, A.; Bousselmi, L.; Jabri, K.M.; Nolde, E.; Ciroth, A.; Bousselmi, L. Life cycle assessment of a decentralized greywater treatment alternative for non-potable reuse application. Int. J. Environ. Sci. Technol. 2019, 17, 433-444. [CrossRef]

12. Magwaza, S.T.; Magwaza, L.S.; Odindo, A.O.; Mditshwa, A. Hydroponic technology as decentralised system for domestic wastewater treatment and vegetable production in urban agriculture: A review. Sci. Total Environ. 2020, 698, 134154. [CrossRef]

13. Bagundol, T.B.; Awa, A.L.; Enguito, M.R.C. Efciency of slow sand filter in purifying well water. J. Multidiscip. Stud. 2013, 2, 86-102.

14. MWRI-GOSS. Technical Guidelines for the Construction and Management of Slow Sand Filters. A Manual for Field Staff and Practitioners; MWRI-GOSS: Khartoum, Sudan, 2009. 
15. Huisman, L.; Wood, W.E. An Introduction to Slow Sand Filtration. Available online: www.itacanet.org (accessed on 10 October 2018).

16. Arden, S.; Ma, X. Constructed wetlands for greywater recycle and reuse: A review. Sci. Total Environ. 2018, 630, 587-599. [CrossRef]

17. Oh, K.S.; Leong, J.Y.C.; Poh, P.E.; Chong, M.N.; Lau, E.V. A review of greywater recycling related issues: Challenges and future prospects in Malaysia. J. Clean. Prod. 2017, 171, 17-29. [CrossRef]

18. Oron, G.; Adel, M.; Agmon, V.; Friedler, E.; Halperin, R.; Leshem, E.; Weinberg, D. Greywater use in Israel and worldwide: Standards and prospects. Water Res. 2014, 58, 92-101. [CrossRef] [PubMed]

19. Selimoğlu, F.; Öbek, E.; Karataş, F.; Arslan, E.I.; Tatar, S.Y. Determination of amounts of some vitamin B groups in domestic wastewater treatment plants. Turk. J. Sci. Technol. 2015, 10, 1-5.

20. Velho, V.F.; Daudt, G.C.; Martins, C.L.; Belli, F.P.; Costa, R.H.R. Reduction of excess sludge production in an activated sludge system based on lysis-cryptic growth, uncoupling metabolism and folic acid addition. Braz. J. Chem. Eng. 2016, 33, 47-57. [CrossRef]

21. Abdel-Raouf, N.; Al-Homaidan, A.A.; Ibraheem, I.B.M. Microalgae and wastewater treatment. Saudi J. Biol. Sci. 2012, 19, 257-275. [CrossRef]

22. Zamalloa, C.; Boon, N.; Verstraete, W. Anaerobic digestibility of Scenedesmus obliquus and Phaeodactylumtricornutum under mesophilic and thermophilic conditions. Appl. Energy 2012, 92, 733-738. [CrossRef]

23. Stover, E.L.; Haas, C.N.; Rakness, K.L.; Scheible, O.K. Design Manual: Municipal Wastewater Disinfection; Environmental Protection Agency: Cincinnati, OH, USA, 1986.

24. White, G.C. Handbook of Chlorination; Van Nostrand Reinhold Company: New York, NY, USA, 1978.

25. Haas, C.N. Assessing the need for wastewater disinfection. J. Water Pollut. Cont. Fed. 1987, 59, 856-864.

26. Water Pollution Control Federation: Disinfection Committee. Wastewater Disinfection: A State-of the-Art Report; Water Pollution Conrtol Federation: Alexandria, VA, USA, 1984.

27. Gonçalves, R.F.; Vaz, L.D.O.; Peres, M.; Merlo, S.S. Microbiological risk from non-potable reuse of greywater treated by anaerobic filters associated to vertical constructed wetlands. J. Water Process. Eng. 2021, 39, 101751. [CrossRef]

28. Rodríguez, C.; Sánchez, R.; Rebolledo, N.; Schneider, N.; Serrano, J.; Leiva, E. Cost-benefit evaluation of decentralized greywater reuse systems in rural public schools in Chile. Water 2020, 12, 3468. [CrossRef]

29. Rossi, G.; Mainardis, M.; Aneggi, E.; Weavers, L.K.; Goi, D. Combined ultrasound-ozone treatment for reutilization of primary effluent-A preliminary study. Environ. Sci. Pollut. Res. 2021, 28, 700-710. [CrossRef]

30. Ucevli, O.; Kaya, Y. A comparative study of membrane filtration, electrocoagulation, chemical coagulation and their hybrid processes for greywater treatment. J. Environ. Chem. Eng. 2021, 9, 104946. [CrossRef] 